\title{
VARIATIONS IN THE YIELD OF COCONUTS, AS INFLUENCED BY THE PATTERN OF RAINFALL AND DURATION OF DRYSPELL
}

\author{
Jacob Mathew, Amarnath C.H., Vijaya Kumar K, \\ Mohamed Yusuf and Balakrishnan T K. ${ }^{1}$
}

\begin{abstract}
Study of the variations in the yield of coconuts in the West Coast of India, in relation to the pattern of rainfall and duration of dryspell revealed that the yield obtained in any year is not directly related with the total rainfall received in the same year or in the preceeding years. Summer rains were having positive correlation with the yield in the succeeding year. About $60 \%$ of the variations in the annual yield were due to the changes in the duration of dryspell in the preceeding two years.

\section{INTRODUCTION}

Weather factors are known to influence crop production, especially under rainfed conditions. In the west coast of India, coconut is grown mostly as a rainfed crop. During the past five decades, many attempts have been made in India, Sri Lanka and Malaysia, to study the relationship between weather factors and yield of coconuts (Patel and Anandan 1936, Abeywardena 1968 and 1983, Balasubramaniam 1956, Lakshmanachar 1963, Marar and Pandalai 1957, Prasada Rao 1984 and 1986, Pankajakshan Nair 1985 and Vijaya Kumar et al 1986). The studies have highlighted the influence of pattem of rainfall, the quantity of precipitation, usefulness of sununer rains and the harmful effects of excess rains received during monsoon period, on yield. The usefulness of relative humidity, sunshine hours, drought index, etc., in predicting the yield was also brought out by some of these studies. In tWs paper, an attempt has been made to study the fluctuations in the annual yield of coconuts, in relation to the pattern of rainfall and duration of dryspell in the preceedings two years.
\end{abstract}

\section{MATERIALS AND METHODS}

The annual yield data of 187 palms in Block E of Central Plantation Crops Research Institute, Kasaragod, located in the west coast of India, for the period 1961 to 1984 were considered in this study. The palms were about 40 - 45 years age in 1961 and were growing under rainfed condition, receiving the recommended doses of fertilizers. Weekly and monthly data on rainfall $(\mathrm{mm})$ and number of rainy days (with not less than $2.5 \mathrm{~mm}$ rain) for the period 1958 to 1984 were coflected from the agro-meteorology Observatory of the Institute and were considered as four seasons, viz. June to August (S. W. monsoon period), September to November (N. E. monsoon period), December to February (Winter) and March to May (Summer). Pearson's coefficient of correlation were worked out between the annual yield of coconuts and the weather factors, both annual (January to December) and seasonal, considering lag periods upto three years. Usefulness of these weather variables for selected periods, in explaining the variations in the annual yield of coconuts, was also examined, using multiple regression models.

\section{RESULTS AND DISCUSSION}

At Kasaragod, the average annual rainfall is nearly 3,500 mm, spread over about 115 days. During the period under consideration it ranged from a lowest of 2,499 in 1964 to a highest of 5,703 $\mathrm{mm}$ in 1961. The number of rainy days varied from 90 in 1979 to 1945 in 1961 (Table I). The mean annual vield per pahn during this period was 64 nuts, the range being 50 nuts in 1965 to 79 nuts in

\footnotetext{
${ }^{1}$ Central Plantation Crops Research Institute, Kasaragod-670 124, Kerala, India.
} 
1970-About 90 per cent of the total rains received in a year were confined to South-West (S. W.) and North-East (N. E.) monsoon periods extending from June to November (Table II). In summer months (March, April and May) only about 8 per cent of the total annual rainfall and 10 per cent of the rainy days were recorded. Monthly data on rainfall showed that during the three months of winter (December to February) and also in March, no rains were received. During April, about 34 $\mathrm{mm}$ of precipitation in two days was recorded. Early onset of the monsoon (during May end) in some of the years, has contributed to the higher share of surnmer rains. Variations over the years, as revealed by the coefficient of variation (C.V.\%) was not high for either the annual or the S. W. monsoon (June to August) rains.

Linear correlations have shown that the yield of nuts obtained in any year is not related to the total rainfall or total number of rainy days in the same year or in any of the preceeding three years (Table III). Consideration of weather data for the preceeding years is of importance because the primordium of the inflorescence is formed about 32 months prior to its opening (Child 1964). Even after the spathe opens, it takes about 12 months for the female flowers to develop into fully ripe nuts. Thus the weather prevailing approximately 44 months prior to the harvesting of nuts will have influence on the nut yield. But the nature and extent of the influence of these factors may vary depending on the stage of development of the inflorescence. When the influence of seasons was considered, rains during summer was found to have favourable effect on subsequent year's yields, whereas the effect was adverse on the yield in the second year. More number of rainy days during N.E. monsoon period was also found to bring down the yield in the succeeding year.

Since the C.V. over the years for rainfall and rainy days are higher during winter and surnmer months, compared to the monsoon periods (Table II), we can presume that the variations in yield between years may probably be due to the pattem of rainfall and/or due to the intensity of dryspell during these periods. When the number of weeks with little or no rains was taken as an index for the intensity of dryspell, strong negative correlations were observed between the yield in any year and the number of weeks with $=2$ rainy days or with $=50 \mathrm{~mm}$ rainfall in the preceding year. However, in the subsequent year the relationship was positive and high (Table III). This explains the low yields obtained in some years $(1965,1974,1980$ etc.) succeeding drought years and the bumper yields, a year later. Inclusion of the period from November to February, along with the surnmer months has not improved the correlation coefficients, probably due to the higher availabihty of soil moisture to the plants, in these months inimediately succeeding the N.E. monsoon period. The effect of low or ill-distributed rains on coconut yields was not found to persist for more than one year. Park (1934) had observed that the severe drought at Puttalam (Sri Lanka) had affected the yield of nuts for two years. Recently Prasada Rao (1986) had pointed out from Pilicode (Kerala, India) that the adverse effect of drought on monthly nut yield was seen in the eight month after the drought period and continued for 12 more months. Perhaps this duration may change depending on the severity of the drought.

The above correlation analysis has shown that, under the conditions prevailing at Kasaragod, the yield of nuts in any year is influenced substantially by the summer rains of the preceeding two years and to a lesser extent by the summer rains of the same year and that of the third year preceeding the. year of harvest. Detailed investigations are needed, using monthly data on yield and weather variables, with different lag periods, to explain the beneficial effect of summer rains on next years yield and its adverse effects, a year later. Multiple regression analysis using all these four variables showed that about 62 to 65 per cent of the variations in annual yield of coconuts are explained by these variables (Table IV), with the regression coefficients corresponding to current year's and third preceding year's data being non-significant. When the analysis was confined to the data on surnmer rains of preceding two years, there was only marginal reduction in the RI values. It is possible that the RI values would have been much higher, if the total drought period had been considered together, so that the delayed onset of monsoon in June in some of the years 
will also be accounted for. In this study this could not be attempted because the analysis was based on the data for seasons alone.

The effect of drought on yield and yield components was studied for a smaH sample of 30 trees. Based on the rainfall and number of rainy days during March, April and May, 1964, 1979 and 1983 could be identified as abnormal (drought) years (Table V). The production of bunches, female flowers and setting percentage in these drought years was severelY affected, in contrast to the immediately preceding and succeeding years.

\section{ACKNOWLEDGEMENTS}

The authors are thankful to the technical staff of AgronomY and Farm sections of the Institute, who were responsible for the collection of yield and weather data, from time to time. They are thankful to their colleagues also, for their valuable suggestions, at different stages of preparation of this paper.

\section{REFERENCES}

Abeywardena V 1968. Forecasting coconut crop using rainfall data - a preliminary study. Ceylon Coconut $Q: 19: 161-176$.

Abeywardena V 1983. Effect of moisture stress and irrigation on yield of coconut in Sri Lanka. In Coconut Research and Development (Ed. N M Nayar) Wiley Eastern Ltd., pp 98106.

Balasubramaniam C 1956. Rainfall and yield of coconut in South Kanara District. Indian Coconut J. 9:207-214.

Child, R. 1974. Coconuts (2 ${ }^{\text {nd }}$ edition) Long Group Ltd. London. 335 pp.

Lakshmanachar, M.S. 1963. Studies on the effect of rainfall on coconut crops. Indian Coconut Bull. 16:370-372.

Mararm M.M. Krishna and Pandalai K.M. 1957. Influence of weather parameters on the coconut crop. Indian J. Met. Geophy. 8: SpI. No. 60-70.

Park, Malcom. 1934. Some notes on the effect of drought on the yield of coconut palms. Trop. Agriculturist. 8:141-150.

Pankajakshan Nair, B. 1985. Influence of weather parameters on the yield of coconut. (unpublished M. SC. (Ag. Stat.) thesis, Kerala Agricultural University).

Patel, J.S. and Anandan, A.P. 1936. Rainfafl and yield in coconut. The Madras agric. J. 24(1):11-22.

Prasad Rao, G. S. L. H. V. 1984. Rainfall and coconut yield in the Pilicode region, North Kerala. In Fifth Annual Symposium on Plantation Crops, C.P.C.R.I., Kasaragod, pp. 388393.

Prasad Rao, G.S.L.H.V. 1986. Effect of drought on coconut production. Indian Coconut J. 17(8):11-12.

Vijay Kumar, K., Nambiar, P.T.N., Jacob, Mathew, Amarnath C.H. and Balakrishnan T.K. 1986. Forecasting yield in coconut using weather varaibles. In Abstract of Papers - Seventh Symposium on Plantation Crops, Coonoor, 1986. pp. 55. 
Table 1 : Yield of coconuts and rainfall at Kasaragod

\begin{tabular}{|c|c|c|c|c|c|r|r|}
\hline Year & $\begin{array}{c}\text { Mean } \\
\text { Yield }\end{array}$ & $\begin{array}{c}\text { Rainfall } \\
(\mathrm{mm})\end{array}$ & $\begin{array}{c}\text { Rainy } \\
\text { Days }\end{array}$ & Year & $\begin{array}{c}\text { Mean } \\
\text { Yield }\end{array}$ & $\begin{array}{c}\text { Rainfall } \\
(\mathrm{mm})\end{array}$ & $\begin{array}{c}\text { Rainy } \\
\text { days }\end{array}$ \\
\hline 1961 & 61.1 & 5,703 & 145 & 1973 & 63.6 & 2,857 & 111 \\
1962 & 61.7 & 3,496 & 130 & 1974 & 55.8 & 3,550 & 118 \\
1963 & 53.0 & 3,077 & 124 & 1975 & 73.1 & 4,332 & 138 \\
1964 & 74.4 & 2,499 & 106 & 1976 & 58.2 & 3,052 & 102 \\
1965 & 50.0 & 3,105 & 100 & 1977 & 63.0 & 3,705 & 123 \\
1966 & 77.2 & 2,998 & 112 & 1978 & 60.0 & 4,655 & 133 \\
1967 & 66.1 & 3,733 & 114 & 1979 & 60.9 & 3,075 & 90 \\
1968 & 63.4 & 4,230 & 105 & 1980 & 51.2 & 3,035 & 122 \\
1969 & 67.0 & 2,934 & 119 & 1981 & 68.1 & 3,367 & 117 \\
1970 & 79.2 & 4,301 & 123 & 1982 & 62.0 & 3,214 & 97 \\
1971 & 62.8 & 3,877 & 110 & 1983 & 72.3 & 3,277 & 113 \\
1972 & 74.3 & 3,076 & 101 & 1984 & 57.6 & 3,243 & 123 \\
\hline
\end{tabular}

Table II : Seasonal distribution of rainfall at Kasaragod (1961-1984)

\begin{tabular}{|l|l|r|r|r|r|}
\hline \multirow{2}{*}{} & \multirow{2}{*}{ Season } & \multicolumn{2}{|c|}{ Rainfall $(\mathrm{mm})$} & \multicolumn{2}{c|}{ Rainy days } \\
\cline { 3 - 6 } & & \multicolumn{1}{c|}{ Mean } & \multicolumn{1}{c|}{ CV\% } & \multicolumn{1}{c|}{ Mean } & \multicolumn{1}{c|}{ CV\% } \\
\hline S.W. Monsoon & (June-August) & $2,612.0$ & 17.9 & 74.6 & 7.9 \\
N.E. Monsoon & (Sept.-Nov.) & 554.1 & 41.9 & 28.5 & 27.3 \\
Winter & (Dec.-Feb.) & 19.6 & 133.3 & 1.1 & 118.5 \\
Summer & (March-May) & 291.2 & 72.1 & 11.5 & 57.7 \\
Annual & (Jan.-Dec.) & $3,476.9$ & 19.8 & 115.7 & 11.3 \\
\hline
\end{tabular}


Table III: Person's coefficient of correlation for annual yield of coconut (1961- 1984) with rainfall and number of rainy days, for different lag period

\begin{tabular}{|c|c|c|c|c|}
\hline \multirow{2}{*}{ Parameters } & \multicolumn{4}{|c|}{ Lag periods (in years) } \\
\hline & 0 & 1 & 2 & 3 \\
\hline Annual rainfall & 0.037 & -0.037 & -0.230 & 0.029 \\
\hline Total number of rainy days & 0.004 & -0.095 & -0.291 & -0.040 \\
\hline Rainfall during winter & 0.057 & 0.087 & 0.173 & 0.024 \\
\hline Rainfall during summer & -0.115 & 0.096 & $-0.482+$ & $-0 / 036$ \\
\hline Rainfall during s.w monsoon & 0.060 & -0.035 & -0.039 & 0.008 \\
\hline Ranfall during n.e. monsoon & 0.125 & -0.181 & -0.212 & 0.038 \\
\hline No, of rainy days during winter & 0.029 & 0.044 & -0.089 & 0.215 \\
\hline No, of rainy days during summer & -0.266 & 0.341 & $-0.568++$ & 0.057 \\
\hline No, of rainy days during s.w. monsoon & -0.027 & 0.008 & 0.071 & 0.370 \\
\hline No, of rainy days during n.e. monsoon & 0.312 & $-0.463+$ & -0.015 & -0.295 \\
\hline Rainfall/Rainy days during November & & & & \\
\hline No, of weeks with $0 \mathrm{~mm}$ rainfall & 0.270 & -0.105 & 0.350 & 0.187 \\
\hline No, of weeks with $=25 \mathrm{~mm}$ rainfall & 0.256 & -0.304 & $0.488+$ & -0.248 \\
\hline No, of weeks with $=50 \mathrm{~mm}$ rainfall & -0.128 & $-0.423+$ & $0.409+$ & -0.293 \\
\hline No, of weeks with $=75 \mathrm{~mm}$ rainfall & -0.018 & -0.138 & $0.581++$ & -0.050 \\
\hline No, of weeks with $=100 \mathrm{~mm}$ rainfall & -0.140 & 0.033 & 0.374 & 0.117 \\
\hline No, of weeks with 0 rainy days & 0.350 & -0.214 & $0.460+$ & -0.169 \\
\hline No, of weeks with $=2$ rainy days & 0.154 & -0.269 & $0.639++$ & -0.396 \\
\hline No, of weeks with $=4$ rainy days & 0.152 & -0.072 & $0.543++$ & -0.091 \\
\hline No, of weeks with $=6$ rainy days & 0.201 & 0.044 & $0.465++$ & -0.108 \\
\hline Rainfall/Rainy days during March-Ma & & & & \\
\hline No, of weeks with $0 \mathrm{~mm}$ rainfall & 0.238 & -0.245 & 0.116 & 0.287 \\
\hline No, of weeks with $=25 \mathrm{~mm}$ rainfall & 0.222 & $-0.420+$ & $0.526++$ & -0.061 \\
\hline No, of weeks with $=50 \mathrm{~mm}$ rainfall & 0.078 & $-0.509++$ & $0.535++$ & -0.154 \\
\hline No, of weeks with $=75 \mathrm{~mm}$ rainfall & 0.003 & -0.231 & $0.509++$ & -0.061 \\
\hline No, of weeks with $=100 \mathrm{~mm}$ rainfall & -0.060 & 0.044 & 0.354 & 0.121 \\
\hline No, of weeks with 0 rainy days & 0.293 & -0.321 & $0.468+$ & -0.049 \\
\hline No, of weeks with $=2$ rainy days & 0.201 & -0.386 & $0.624++$ & -0.232 \\
\hline No, of weeks with $=4$ rainy days & 0.141 & -0.121 & $0.491+$ & -0.111 \\
\hline No, of weeks with $=6$ rainy days & 0.201 & 0.014 & $0.465+$ & -0.108 \\
\hline
\end{tabular}

+ Significant at $\mathrm{P}=0.05 \quad++$ Significant at $\mathrm{P}=0.01$ 
Table IV: Multiple regression models showing the relationship between the yield of coconuts and the pattern of rainfall during summer months in the year of harvest and preceding years.

\begin{tabular}{|c|c|c|c|c|c|c|}
\hline \multirow[t]{2}{*}{ Parameters } & \multirow{2}{*}{$\begin{array}{c}\text { Constant } \\
\text { term }\end{array}$} & \multicolumn{5}{|c|}{$\begin{array}{l}\text { Regression coefts. Corresponding to } \\
\text { Different lag periods (in years) }\end{array}$} \\
\hline & & 0 & 1 & 2 & 3 & $\mathrm{R}^{2}$ \\
\hline $\begin{array}{l}\text { Number of weeks } \\
\text { with } \\
=2 \text { rainy days } \\
\text { during March-May }\end{array}$ & 52.46 & $\begin{array}{r}0.9509 \\
(0.8817)\end{array}$ & $\begin{array}{r}-2.3953 \\
(0.8125)\end{array}$ & $\begin{array}{l}3.887++ \\
(0.8360)\end{array}$ & $\begin{array}{r}-1.3969 \\
(0.8653)\end{array}$ & 0.65 \\
\hline & 48.98 & & $\begin{array}{r}-2.6086++ \\
(0.8226)\end{array}$ & $\begin{array}{r}3.9662++ \\
(0.8461)\end{array}$ & & 0.59 \\
\hline $\begin{array}{l}\text { No. of weeks with } \\
=50 \mathrm{~mm} \text { rainfall }\end{array}$ & & $\begin{array}{r}0.7815 \\
(0.8769)\end{array}$ & $\begin{array}{r}-3.7815++ \\
(0.8016)\end{array}$ & $\begin{array}{r}3.6684++ \\
(0.7986)\end{array}$ & $\begin{array}{r}-1.2851 \\
(0.82 .17)\end{array}$ & 0.67 \\
\hline during March-May & 63.23 & & $\begin{array}{r}-3.5350++ \\
(0.8144)\end{array}$ & $\begin{array}{r}3.6569++ \\
(0.8113)\end{array}$ & & 0.62 \\
\hline
\end{tabular}

++ Significant at $\mathrm{P}=0.01$

Figures in parenthesis denote the S.Es of regression coefficients.

Table V : Incidence of drought and its effect on yield attributes

\begin{tabular}{|c|c|c|c|}
\hline Parameter & & $\begin{array}{c}1964 \\
1979 \\
1983 \\
\text { (mean) }\end{array}$ & $\begin{array}{c}1963,65 \\
1978,80 \\
1982,84 \\
\text { (mean) }\end{array}$ \\
\hline $\begin{array}{ll}\text { Rainfall }(\mathrm{mm}) \text { during } & \text { March-May } \\
& \text { June-Augus } \\
& \text { Annual }\end{array}$ & & $\begin{array}{r}24 \\
2,349 \\
2,924\end{array}$ & $\begin{array}{r}340 \\
2,505 \\
3,327\end{array}$ \\
\hline $\begin{array}{ll}\text { Rainy days during } & \text { March-May } \\
& \text { June-Augus } \\
\text { Annual }\end{array}$ & & $\begin{array}{r}2 \\
71 \\
101\end{array}$ & $\begin{array}{r}14 \\
78 \\
119\end{array}$ \\
\hline Production of bunches during & $\begin{array}{l}\text { March-May } \\
\text { June-August } \\
\text { Annual }\end{array}$ & $\begin{array}{l}2.12 \\
2.42 \\
9.86\end{array}$ & $\begin{array}{r}3.16 \\
2.78 \\
10.96\end{array}$ \\
\hline Production of femal flowers during & $\begin{array}{l}\text { March-May } \\
\text { June-August } \\
\text { Annual }\end{array}$ & $\begin{array}{r}29.3 \\
33.4 \\
133.3\end{array}$ & $\begin{array}{r}41.8 \\
40.6 \\
144.5\end{array}$ \\
\hline Setting percentage during & $\begin{array}{l}\text { March-May } \\
\text { June-August } \\
\text { Annual }\end{array}$ & $\begin{array}{l}36.3 \\
34.3 \\
36.9\end{array}$ & $\begin{array}{l}45.2 \\
41.0 \\
44.0\end{array}$ \\
\hline
\end{tabular}

